Available online at http://journal.stkip-andi-matappa.ac.id/index.php/histogram/index

Histogram : Jurnal Pendidikan Matematika 2 (2), 2018, 183-194

\title{
EFEKTIVITAS PENERAPAN METODE PEMBELAJARAN HYPNOTEACHING TERHADAP HASIL BELAJAR MATEMATIKA
}

\author{
Akbar Taufik ${ }^{1}$, Suryanti ${ }^{2}$ \\ Universitas Pancasakti Makassar ${ }^{1,2}$ \\ * Corresponding Author. Email: akbartaufik@unpacti.ac.id
}

Received: 31 July 2018; Revised: 21 September 2018; Accepted: 27 September2018

\begin{abstract}
ABSTRAK
Jenis penelitian ini adalah penelitian eksperimen dengan subjek penelitian kelas VIII-7 dan VIII-8 MTsN 1 Kota Makassar. Tujuan penelitian: (1) Untuk mengetahui deskripsi hasil belajar siswa kelas VIII setelah dilaksanakan pembelajaran dengan metode pembelajaran hypnoteaching dan metode ceramah, (2) Untuk mengetahui keaktifan siswa kelas VIII dalam pembelajaran dengan metode hypnoteaching dan metode caramah, dan (3) Untuk mengetahui respons siswa kelas VIII terhadap metode pembelajaran hypnoteaching dan metode caramah, (4) Untuk mengetahui hasil belajar mana yang lebih baik antara metode pembelajaran hypnoteaching dengan metode ceramah. Teknik analisis data dilakukan dengan menggunakan teknik statistika deskriptif dan inferensial. Hasil penelitian menunjukkan bahwa: (1) Rata-rata hasil belajar matematika yang diajar dengan metode pembelajaran hypnoteaching lebih baik dibandingkan yang diajar dengan metode ceramah. Rata-rata hasil belajar matematika siswa yang diajar dengan metode pembelajaran hypnoteaching adalah 82,90 lebih tinggi dibandingkan yang diajar dengan metode ceramah yakni 78,25, (2) Keaktifan siswa dalam proses belajar mengajar yang diajar dengan menggunakan metode pembelajaran hypnoteaching lebih baik, (3) Respons siswa yang diajar dengan menggunakan metode pembelajaran hypnoteaching sama positifnya dengan respons siswa yang diajar dengan menggunakan metode ceramah, dan (4) metode pembelajaran hypnoteaching lebih efektif diterapkan pada siswa kelas VIII MTsN 1 Kota Makassar.
\end{abstract}

Kata kunci: Efektivitas, Metode Hypnoteaching, Hasil Belajar

How to Cite: Taufik, A., Suryanti. (2018). Efektivitas penerapan metode pembelajaran Hypnoteaching terhadap hasil belajar matematika. Histogram: Jurnal Pendidikan Matematika, 2(2), 183-194. doi: http://dx.doi.org/10.31100/histogram.v2i2.206

Permalink/DOI:

http://dx.doi.org/10.31100/histogram.v2i2.206

\section{PENDAHULUAN}

Masalah yang sangat menonjol dari kurangnya minat dan kesenangan siswa terhadap mata pelajaran matematika adalah hasil belajar para siswa yang belum memuaskan, kenyataan itu sangatlah memprihatinkan khususnya bagi dunia pendidikan kita. Pada umumnya pembelajaran matematika yang ditemui selama ini masih menekankan pada tuntutan kurikulum dan penyampaian tekstual semata daripada mengembangkan kemampuan belajar dan membangun individu. Kondisi ini tidak akan menumbuh kembangkan aspek kemampuan dan aktivitas siswa seperti yang diharapkan. 


\section{Histogram: Jurnal Pendidikan Matematika, 2 (2), 2018 - 184 Akbar Taufik, Suryanti}

Salah satu metode pembelajaran yang dianggap mampu mengefektifkan dan meningkatkan prestasi belajar siswa yaitu hypnoteaching. Dalam pelaksanaannya, metode pembelajaran ini memiliki empat karakteristik yaitu yelling, jam emosi, ajarkan dan puji, serta pertanyaan ajaib.

Pembelajaran menggunakan hypnoteaching bertujuan untuk mengefektifkan proses pembelajaran tersebut agar menjadi lebih menyenangkan dan dapat menumbuhkan fokus penuh perhatian dari siswa. Guru dapat menggunakan teknikteknik pembelajaran yang tepat untuk mencapai tujuan pembelajaran yang optimal (Yustisia, 2012:74).

Selama pembelajaran, guru berusaha memfokuskan perhatian siswa dengan menggunakan bahasa-bahasa bawah sadar (persuasif) dalam menyampaikan materi pelajaran yang menimbulkan ketertarikan tersendiri bagi siswa sehingga informasi yang diterima dapat diserap secara maksimal oleh otak. Setelah memperoleh materi pelajaran tersebut, siswa diharapkan dapat menerapkan ilmu yang diterima dalam menyelesaikan soal sehingga kesalahan-kesalahan seperti kesalahan penggunaan data, kesalahan teorema, kesalahan teknik, dan kesalahan lain dapat berkurang.

Beberapa hasil penelitian menunjukkan bahwa metode pembelajaran hypnoteaching efektif digunakan dalam pembelajaran matematika dan dapat meningkatkan ketuntasan belajar siswa. Salah satunya jurnal Hasbullah \& Rahmawati (2015) tentang Pengaruh Penerapan Metode Hypnoteaching Terhadap Motivasi Belajar Mahasiswa Universitas Indraprasta PGRI dan jurnal Dian Nurul Safitri \& Nelly Indriastuti Purnamasari (2017) tentang Efektivitas Pembelajaran Matematika Dengan Hypnoteaching Terhadap Prestasi Mahasiswa Pada Mata Kuliah Geometri II IKIP PGRI Bojonegoro.

Secara umum rumusan masalah dalam penelitian ini adalah 1) Bagaimana deskripsi hasil belajar siswa kelas VIII sesudah pelaksanaan pembelajaran dengan metode hypnoteaching dan ceramah? 2) Bagaimana keaktifan siswa kelas VIII dalam pembelajaran dengan metode hypnoteaching dan ceramah? 3) Bagaimana respons siswa kelas VIII terhadap pembelajaran dengan metode hypnoteaching dan ceramah? 4) Apakah hasil belajar belajar matematika siswa yang diajar dengan metode pembelajaran hypnoteaching lebih baik daripada siswa yang diajar dengan metode ceramah? 


\section{Histogram: Jurnal Pendidikan Matematika, 2 (2), 2018 - 185 \\ Akbar Taufik, Suryanti}

\section{METODE PENELTIAN}

Penelitian ini merupakan penelitian eksperimen yang melibatkan dua kelompok siswa yang diberi perlakuan yang berbeda. Kelompok pertama diajar dengan menggunakan metode pembelajaran hypnoteaching yaitu kelas VIII-7 MTsN 1 Kota Makassar dan disebut kelompok eksperimen, sedangkan kelompok kedua diajar dengan menggunakan metode ceramah yaitu kelas VIII-8 MTsN 1 Kota Makassar dan disebut kelompok kontrol. Variabel dalam penelitian ini ada dua jenis, yakni variabel bebas dan variabel terikat. Variabel bebasnya adalah pembelajaran metode hypnoteaching dan pembelajaran metode ceramah, sedangkan variabel terikatnya adalah hasil belajar siswa. Desain yang digunakan dalam penelitian ini adalah Posttest only control group design.

Subjek penelitian ini dipilih secara cluster random sampling dua kelas. Dari dua kelas yang terpilih selanjutnya ditentukan secara acak untuk menetapkan kelas kontrol yang menggunakan metode ceramah dan kelas eksperimen yang menggunakan metode hypnoteaching. Adapun instrumen penelitian yang digunakan adalah 1) Tes, Untuk memperoleh data tentang hasil belajar matematika siswa sebelum dan sesudah diberikan perlakuan, digunakan satu perangkat alat instrumen yaitu tes hasil belajar. Bentuk tes yang digunakan adalah bentuk uraian, 2) Lembar keterampilan proses/aktivitas siswa, Instrumen ini digunakan untuk memperoleh data tentang aktivitas siswa selama proses pembelajaran berlangsung. Komponen-komponen penilaian berkaitan dengan aktivitas siswa termasuk perhatian, kesungguhan, kedisiplinan, kerjasama siswa dan keterampilan siswa, 3) Angket respons siswa, Angket respons siswa dirancang untuk mengetahui respons siswa terhadap metode pembelajaran yang diberikan. Aspek respons siswa menyangkut suasana kelas, minat mengikuti pembelajaran berikutnya, cara-cara guru mengajar dan saran-saran.

Pengumpulan data untuk hasil belajar siswa dilakukan dengan pemberian tes pada awal sebelum diberi perlakuan dan pada akhir perlakuan secara serentak kepada masingmasing responden pada kedua kelompok, yatu kelompok eksperimen dan kelompok kontrol. Data yang diperoleh merupakan data empirik yang kemudian akan dianalisis.

Metode observasi menggunakan lembar pengamatan keterampilan proses peserta didik untuk mengamati kegiatan peserta didik yang diharapkan muncul dalam pembelajaran matematika dengan metode hypnoteaching. Teknik yang digunakan untuk memperoleh data respons tersebut adalah dengan membagikan angket kepada siswa 


\section{Histogram: Jurnal Pendidikan Matematika, 2 (2), 2018 - 186 \\ Akbar Taufik, Suryanti}

setelah berakhirnya pertemuan terakhir untuk diisi sesuai dengan petunjuk yang diberikan.

Teknik analisis data yang digunakan dalam penelitian ini adalah:

1. Tes hasil belajar

a. Analisis statistik deskriptif

Analisis statistik deskriptif menekankan pada pembahasan data-data dan subjek penelitian dengan menyajikan data-data secara sistematik. Analisis statistik desktiptif digunakan untuk mendeskripsikan hasil belajar siswa untuk masing-masing kelompok penelitian. Analisis ini meliputi nilai mean (rata-rata), standar deviasi, nilai maksimun, nilai minimum, dan tabel disribusi frekuensi. Jenis data berupa hasil belajar selanjutnya dikategorikan secara kualitatif seperti tabel 1 di bawah ini:

Tabel 1. Interpretasi Kategori Nilai Hasil Belajar

\begin{tabular}{cc}
\hline $\begin{array}{c}\text { Nilai Hasil } \\
\text { Belajar }\end{array}$ & Kategori \\
\cline { 2 - 2 } $85-100$ & Sangat Tinggi \\
$65-84$ & Tinggi \\
$55-64$ & Cukup \\
$35-54$ & Rendah \\
$0-34$ & Sangat Rendah \\
\hline
\end{tabular}

(Sumber: Depdikbud, Tahun : 2009)

Di samping itu hasil belajar siswa juga diarahkan pada pencapaian hasil belajar secara individual dan klasikal. Kriteria seorang siswa dikatakan tuntas belajar apabila memenuhi kriteria ketuntasan minimal yang ditentukan oleh sekolah, sedangkan ketuntasan klasikal tercapai apabila minimal $80 \%$ siswa dikelas tersebut telah mencapai skor ketuntasan minimal.

b. Analisis Statistik Inferensial

Analisis statistika inferensial digunakan untuk menguji hipotesis penelitian dengan analisis Independent-Samples T Test. Namun sebelum dilakukan pengujian hipotesis terlebih dahulu dilakukan uji prasyarat atau uji asumsi yang meliputi uji normalitas dan uji homogenitas. b. Keterampilan proses/aktivitas siswa

Data hasil pengamatan keterampilan proses siswa yang diambil dari lembar observasi kemudian dianalisis dengan cara teknik analisis data kualitatif. Kriteria keberhasilan aktivitas siswa dalam penelitian ini ditunjukkan dengan lebih aktifnya siswa 
Histogram: Jurnal Pendidikan Matematika, 2 (2), 2018 - 187

Akbar Taufik, Suryanti

dalam proses pembelajaran di kelas eksperimen dibandingkan dengan siswa yang di kelas kontrol.

c. Respons siswa

Data tentang respons siswa diperoleh dari angket respon siswa yang kemudian dianalisis dengan menggunakan teknik analisis kualitatif. Kriteria yang ditetapkan dalam penelitian ini adalah lebih banyaknya siswa yang memberikan respons positif terhadap metode hypnoteaching dibandingkan dengan metode ceramah

\section{HASIL DAN PEMBAHASAN}

\section{A. Deskripsi Hasil Belajar Kelas Eksperimen (sebelum treatment)}

Untuk memberikan gambaran awal tentang prestasi belajar matematika siswa pada kelas eksperimen, berikut disajikan deskripsi skor hasil belajar kelas tersebut. Deskripsi dan persentase skor kemampuan awal matematika siswa kelas eksperimen sebelum diberikan perlakuan, nilai tersebut diambil dari nilai semester sebelumnya. 
Tabel 2. Deskripsi Skor kemampuan awal Matematika Siswa Kelas Eksperimen Sebelum Diberikan Perlakuan

\begin{tabular}{cc}
\hline Statistik & Nilai Statistik \\
\hline Ukuran Sampel & 39 \\
Nilai Terendah & 75 \\
Nilai Tertinggi & 80 \\
Nilai Rata-Rata & 76,23 \\
Standar Deviasi & 14,23 \\
\hline
\end{tabular}

(Sumber: Data Primer, Tahun: 2018)

Tabel 3. Distribusi dan Persentase Skor Kemampuan Awal Matematika Siswa Kelas Eksperimen Sebelum Diberikan Perlakuan

\begin{tabular}{|c|c|c|c|c|}
\hline No & Skor & Kategori & Frekuensi & Persentase \\
\hline 1. & $<55$ & Sangat Rendah & 0 & $0 \%$ \\
\hline 2. & $55-64$ & Rendah & 0 & $0 \%$ \\
\hline 3. & $65-79$ & Sedang & 36 & $92,31 \%$ \\
\hline 4. & $80-89$ & Tinggi & 3 & $7,69 \%$ \\
\hline 5. & $90-100$ & Sangat Tinggi & 0 & $0 \%$ \\
\hline \multicolumn{3}{|c|}{ JUMLAH } & 39 & $100 \%$ \\
\hline
\end{tabular}

(Sumber: Data Primer, Tahun: 2018)

1. Kelas Kontrol (sebelum treatment)

Tabel 4. Deskripsi Skor Kemampuan Awal Matematika Siswa Kelas Kontrol Sebelum Diberikan Perlakuan

\begin{tabular}{cc}
\hline Statistik & Nilai Statistik \\
\hline Ukuran Sampel & 40 \\
Nilai Terendah & 75 \\
Nilai Tertinggi & 80 \\
Nilai Rata-Rata & 75,90 \\
Standar Deviasi & 13,36 \\
\hline
\end{tabular}

(Sumber: Data Primer, Tahun: 2018)

Tabel 5. Distribusi dan Persentase Skor Kemampuan Awal Matematika Siswa Kelas

\begin{tabular}{|c|c|c|c|c|}
\hline \multicolumn{5}{|c|}{ Kontrol Sebelum Diberikan Perlakuan } \\
\hline No & Skor & Kategori & Frekuensi & Persentase (\%) \\
\hline 1. & $<55$ & Sangat Rendah & 0 & 0 \\
\hline 2. & $55-64$ & Rendah & 0 & 0 \\
\hline 3. & $65-79$ & Sedang & 38 & $95 \%$ \\
\hline 4. & $80-89$ & Tinggi & 2 & $5 \%$ \\
\hline 5. & $90-100$ & Sangat Tinggi & 0 & $0 \%$ \\
\hline \multicolumn{3}{|c|}{ JUMLAH } & 40 & $100 \%$ \\
\hline
\end{tabular}

(Sumber: Data Primer, Tahun: 2018)

Berdasarkan data pada Tabel 2, Tabel 3, Tabel 4 dan Tabel 5 di atas dapat digambarkan bahwa dari kedua kelas yaitu kelompok eksperimen dan kelompok kontrol, pada umumnya memiliki tingkat prestasi belajar matematika yang sama. Atau dengan kata lain kemampuan 


\section{Histogram: Jurnal Pendidikan Matematika, 2 (2), 2018 - 189 \\ Akbar Taufik, Suryanti}

awal siswa pada kedua kelompok tersebut dapat dikatakan sama, sehingga kedua kelompok tersebut dapat digunakan sebagai subjek penelitian ini.

2. Kelas Eksperimen (setelah treatment)

Tabel 6. Deskripsi skor hasil belajar kognitif siswa yang diajar dengan Metode

\begin{tabular}{cc}
\multicolumn{3}{c}{ Hypnoteaching } \\
\hline Statistik & Nilai Statistik \\
Ukuran Sampel & 39 \\
Nilai Terendah & 75 \\
Nilai Tertinggi & 98 \\
Nilai Rata-Rata & 82,90 \\
Standar Deviasi & 55,86 \\
\hline
\end{tabular}

(Sumber: Data Primer, Tahun: 2018)

Tabel 7. Distribusi dan persentase skor hasil belajar kognitif siswa yang diajar dengan

\begin{tabular}{|c|c|c|c|c|}
\hline \multicolumn{5}{|c|}{ Metode Hypnoteaching } \\
\hline No & Skor & Kategori & Frekuensi & Persentase \\
\hline 1. & $<55$ & Sangat Rendah & 0 & $0 \%$ \\
\hline 2. & $55-64$ & Rendah & 0 & $0 \%$ \\
\hline 3. & $65-79$ & Sedang & 12 & $30,77 \%$ \\
\hline 4. & $80-89$ & Tinggi & 23 & $58,97 \%$ \\
\hline 5. & $90-100$ & Sangat Tinggi & 4 & $10,26 \%$ \\
\hline \multicolumn{3}{|c|}{ JUMLAH } & 39 & $100 \%$ \\
\hline
\end{tabular}

(Sumber: Data Primer, Tahun: 2018)

Tabel 8. Distribusi dan persentase kriteria ketuntasan hasil belajar kognitif siswa yang

\begin{tabular}{|c|c|c|c|c|}
\hline No. & Skor & Kategori & Frekuensi & Persentase (\%) \\
\hline 1 & $<75$ & Tidak Tuntas & 0 & $0 \%$ \\
\hline 2 & $\geq 75$ & Tuntas & 39 & $100 \%$ \\
\hline
\end{tabular}

(Sumber: Data Primer, Tahun: 2018)

Berdasarkan tabel 8 dapat digambarkan bahwa dari 39 siswa yang dijadikan sampel penelitian untuk kelas eksperimen mencapai ketuntasan $100 \%$ artinya siswa yang diajar dengan metode hypnoteaching mencapai ketuntasan klasikal.

3. Kelas Kontrol (setelah treatment)

Tabel 9. Deskriptif skor hasil belajar kognitif siswa yang diajar dengan metode ceramah

Statistik

Ukuran Sampel

Nilai Terendah

Nilai Tertinggi

Nilai Rata-Rata

Standar Deviasi
Nilai Statistik

40
64
88
78,25
64,60

(Sumber: Data Primer, Tahun: 2018) 


\section{Histogram: Jurnal Pendidikan Matematika, 2 (2), 2018 - 190 Akbar Taufik, Suryanti}

Tabel 10. Distribusi dan Persentase Skor Hasil Belajar Kognitif Siswa yang Diajar dengan metode ceramah

\begin{tabular}{ccccc}
\hline No & Skor & Kategori & Frekuensi & Persentase (\%) \\
\hline 1. & $<55$ & Sangat rendah & 0 & $0 \%$ \\
2. & $55-64$ & Rendah & 1 & $2,5 \%$ \\
3. & $65-79$ & Sedang & 22 & $55 \%$ \\
4. & $80-89$ & Tinggi & 17 & $42,5 \%$ \\
5. & $90-100$ & Sangat Tinggi & 0 & $0 \%$ \\
\hline \multicolumn{7}{r}{ Jumlah } & & $\mathbf{4 0}$ & $\mathbf{1 0 0} \%$ \\
\hline
\end{tabular}

(Sumber: Data Primer, Tahun: 2018)

Tabel 11. Distribusi dan persentase kriteria ketuntasan hasil belajar kognitif siswa yang diajar dengan pengajaran langsung

\begin{tabular}{|c|c|c|c|c|}
\hline No. & Skor & Kategori & Frekuensi & Persentase (\%) \\
\hline 1 & $<75$ & Tidak Tuntas & 8 & $20 \%$ \\
\hline 2 & $\geq 75$ & Tuntas & 32 & $80 \%$ \\
\hline \multicolumn{3}{|c|}{ Jumlah } & 40 & 100 \\
\hline
\end{tabular}

(Sumber: Data Primer, Tahun: 2018)

Berdasarkan tabel 11 dapat digambarkan bahwa $80 \%$ siswa yang dijadikan sampel penelitian untuk kelas kontrol mencapai ketuntasan artinya siswa yang diajar dengan metode ceramah mencapai ketuntasan klasikal.

\section{B. Observasi Aktivitas Guru}

\section{Kelas Eksperimen}

Instrumen observasi guru digunakan untuk melihat aktivitas guru dalam mengajar berkaitan dengan keterlaksanaannya metode yang digunakan. Kegiatan observasi terhadap guru dalam pengelolaaan selama proses pembelajaran dilaksanakan yakni mulai dari awal pertemuan pertama sampai akan dilaksanakannya tes. Berdasarkan hasil observasi yang dilakukan oleh pengamat bahwa pada awal-awal pertemuan terdapat banyak kekurangan. Khususnya pada tahap pendahuluan, dimana cara guru dalam menyampaikan tujuan pembelajaran belum jelas, selain itu pemberian motivasi yang tidak terlalu berhubungan dengan materi yang diajarkan sehingga siswa tidak termotivasi dengan materi yang akan disampaikan. Selain itu pengamat juga mencatat beberapa langkah dalam metode pembelajaran hypnoteaching yang belum diterapkan di pertemuan awal.

Pada pertemuan berikutnya terlihat adanya peningkatan dari cara mengajar dan memotivasi siswa, sehingga siswa sudah mulai tertarik untuk memperhatikan materi. Sampai berakhirnya pertemuan secara keseluruhan penampilan guru (peneliti) dalam menerapkan tindakan saat proses belajar mengajar semakin membaik, namun masih memerlukan perbaikan- perbaikan, utamanya pada kelemahan atau kekurangan yang paling menonjol ditiap pertemuan.

Instrumen observasi guru digunakan untuk melihat aktivitas guru dalam mengajar berkaitan dengan keterlaksanaannya metode yang digunakan. Kegiatan observasi terhadap guru dalam pengelolaaan selama proses pembelajaran di kelas kontrol yang dilaksanakan yakni mulai dari awal 


\section{Histogram: Jurnal Pendidikan Matematika, 2 (2), 2018 - 191 \\ Akbar Taufik, Suryanti}

pertemuan pertama sampai akan dilaksanakannya tes. Berdasarkan hasil observasi yang dilakukan oleh pengamat bahwa pada awal-awal pertemuan terdapat banyak kekurangan. Yakni dalam hal menyiapkan siswa untuk belajar, guru masih sangat sulit untuk mengatur siswa. Begitu juga saat guru menyajikan materi, siswa masih banyak yang kurang memperhatikan penjelasan guru dan cenderung mereka acuh untuk memperhatikan.

Selain itu pada saat meminta siswa untuk mengerjakan di papan tulis, guru masih sulit untuk mengajak siswa agar mau naik mengerjakan di papan tulis. Pada tahap penutupan pembelajaran guru mengajak siswa untuk sama-sama merangkum materi yang telah dipelajari dan kemudian guru memberikan tugas untuk dikerjakan di rumah.

Untuk pertemuan berikutnya sampai berakhirnya pertemuan secara keseluruhan penampilan guru dalam menerapkan tindakan saat proses belajar mengajar semakin membaik dan sudah bisa dalam mengontrol siswa-siswa yang kurang tertarik untuk belajar, namun masih memerlukan perbaikan-perbaikan, utamanya pada kelemahan atau kekurangan yang paling menonjol ditiap pertemuan.

\section{Observasi Aktivitas Siswa}

\section{Kelas Eksperimen}

Kegiatan observasi dilakukan selama penelitian dilaksanakan yakni mulai dari awal pertemuan sampai berakhirnya tes. Umumnya siswa selalu tenang pada saat dimulai pelajaran, tenang dalam mendengarkan guru mengabsen. Frekuensi kehadiran siswa juga cukup baik, hanya pada pertemuan 2 terdapat 2 siswa sakit dan 3 orang siswa yang alfa serta dipertemuan 4 tercatat 1 siswa yang tidak hadir berhubung karena minta izin, begitu juga pada pertemuan ke 5 tercatat 2 orang siswa yang sakit dan 2 orang yang alfa.

Secara keseluruhan aktivitas siswa dalam proses pembelajaran masih perlu ditingkatkan. Dari catatan hasil observasi pada pertemuan pertama terlihat masih banyak siswa yang hanya mengandalkan temannya pada saat mengerjakan soal dan ada sebagian yang masih bermain-main dan mengganggu teman. Tetapi pertemuan selanjutnya tercatat sudah terlihat antusiasme siswa dalam kegiatan pembelajaran yang dilaksanakan dengan metode hypnoteaching.

Hingga berkhirnya pertemuan terlihat siswa cenderung lebih aktif dan antusias dalam pelaksaan belajar mengajar di kelas. Mereka sudah tidak canggung ataupun malu untuk bertanya apabila ada yang mereka tidak mengerti. 


\section{Histogram: Jurnal Pendidikan Matematika, 2 (2), 2018 - 192 Akbar Taufik, Suryanti}

Kegiatan observasi dilakukan selama penelitian dilaksanakan yakni mulai dari awal pertemuan sampai berakhirnya tes. Umumnya siswa selalu tenang pada saat dimulai pelajaran, tenang dalam mendengarkan guru mengabsen walaupun ada beberapa yang masih ribut. Frekuensi kehadiran siswa juga cukup baik, hanya pada pertemuan 3 terdapat 1 orang siswa yang alfa serta dipertemuan 5 tercatat 1 siswa yang tidak hadir berhubung karena minta izin.

Dari catatan hasil observasi terlihat di pertemuan pertama masih kurangnya perhatian siswa untuk mengikuti pelajaran ataupun memperhatikan pemaparan materi dari guru. Begitu juga dipertmuan ke 2, siswa masih cenderung santai dan tidak terlalu memperhatikan penjelasan yang disampaikan oleh guru.

Di pertemuan selanjutnya hingga berakhirnya pertemuan, siswa sudah terlihat rajin dan mau meperhatikan penjelasan yang diberikan. Dari keseluruhan pertemuan terlihat jelas kurangnya dominasi aktivitas siswa dalam proses pembelajaran, mereka masih cenderung menerima apa yang disampaikan oleh guru tanpa mau mencari.

\section{Respons Siswa}

\section{Kelas Eksperimen}

Instrumen yang digunakan untuk memperoleh data respons siswa adalah angket respons siswa. Angket ini diberikan pada saat berakhirnya tes yang kemudian siswa diminta untuk mengisi angket yang diberikan.

Dari hasil angket respons siswa, terlihat rata-rata siswa menjawab senang terhadap metode pembelajaran yang diberikan. Mereka senang dengan metode hypnoteaching dengan alasan mereka lebih tenang dan rileks selama proses pembelajaran berlangsung.

\section{Kelas Kontrol}

Instrumen yang digunakan untuk memperoleh data respons siswa adalah angket respons siswa. Angket ini diberikan pada saat berakhirnya tes yang kemudian siswa diminta untuk mengisi angket yang diberikan.

Dari hasil angket respons siswa, terlihat rata-rata siswa juga menjawab senang terhadap metode pembelajaran yang diberikan. Mereka senang dengan alasan mereka lebih suka mendapat penjelasan langsung dari guru, ada juga yang menjawab karena mereka senang pada saat mengerjakan soal dipapan tulis. Namun ada juga beberapa yang kurang senang terhadap metode yang diberikan, dengan alasan mereka tidak suka jika disuruh untuk mengerjakan soal. E.

\section{E. Analisis Inferensial}

Dari keseluruhan jawaban hasil respons siswa terlihat rata-rata siswa senang dengan metode yang diajarkan pada masing-masing kelas, yaitu kelas eksperimen dan kelas kontrol. 


\section{Histogram: Jurnal Pendidikan Matematika, 2 (2), 2018 - 193 \\ Akbar Taufik, Suryanti}

Sebelum dilakukan pengujian hipotesis, dilakukan terlebih dahulu uji prasyarat yaitu uji normalitas dan uji homgenitas. Hasil uji normalitas untuk hasil belajar di kelas eksperimen diperoleh nilai pvalue > alfa yaitu 0,192 >0,05, sedangkan untuk kelas kontrol diperoleh nilai p-value > alfa yaitu $0,174>0,05$, ini berarti hasil belajar keduanya termasuk kategori normal.

Selanjutnya hasil uji homogenitas diperoleh $\mathrm{p}$-value $>$ alfa yaitu $0,463>0,05$ dari hasil ini dapat dikatakan bahwa hasil belajar di kedua sampel yang diambil adalah sama/ homogen. Prasyarat telah dilakukan maka selanjutnya uji hipotesis, yang diperoleh p-value < alfa maka dapat ditarik kesimpulan bahwa H0 ditolak yatu hasil belajar matematika siswa kelas VIII yag diajar dengan Metode Pembelajaran Hypnoteaching lebih baik dibandingkan yang diajar dengan metode ceramah.

\section{KESIMPULAN DAN SARAN}

Berdasarkan hasil analisis data dan pembahasan maka dapat ditarik beberapa kesimpulan sebagai berikut:

1. Rata-rata hasil belajar matematika yang diajar dengan metode pembelajaran hypnoteaching lebih baik dibandingkan yang diajar dengan metode ceramah. Rata-rata hasil belajar matematika siswa yang diajar dengan metode pembelajaran hypnoteaching lebih tinggi dibandingkan yang diajar dengan metode ceramah.

2. Aktivitas siswa dalam proses belajar mengajar yang diajar dengan menggunakan metode pembelajaran hypnoteaching lebih baik dibandingkan aktivitas siswa dalam proses belajar mengajar yang diajar dengan menggunakan metode ceramah.

3. Respons siswa yang diajar dengan menggunakan metode pembelajaran hypnoteaching sama positifnya dengan respons siswa yang diajar dengan menggunakan metode ceramah.

4. Berdasarkan kriteria keefektifan yang telah ditetapkan, maka metode pembelajaran hypnoteaching efektif diterapkan pada siswa kelas VIII MTsN 1 Kota Makassar begitupun dengan metode ceramah, namun setalah dianalisis dan dibandingkan maka dapat dikatakan metode pembelajaran hypnoteaching lebih baik/efektif diterapkan pada siswa kelas VIII MTsN 1 Kota Makassar daripada metode ceramah.

Berdasarkan kesimpulan yang telah dikemukakan, maka penulis mengajukan saran :

1. Penggunaan metode pembelajaran hypnoteaching perlu dipertimbangkan dalam pembelajaran matematika sebagai salah satu metode pembelajaran yang dapat meningkatkan prestasi belajar siswa.

2. Penelitian seperti ini seyogyanya juga dilakukan pada pokok bahasan atau materi lain untuk membuat siswa tertarik, senang, dan aktif dalam belajar matematika. 


\section{Histogram: Jurnal Pendidikan Matematika, 2 (2), 2018 - 194 Akbar Taufik, Suryanti}

3. Untuk penelitian selanjutnya, bagi peneliti yang berminat mengembangkan penelitian yang sama, hendaknya mencermati keterbatasan penelitian ini, sehingga hasil penelitiannya dapat lebih berkualitas dan lebih sempurna.

\section{DAFTAR PUSTAKA}

Budiarso, A, S. (2016). Pengembangan Bahan Ajar Berbasis Metode Hypnoteaching Untuk Memotivasi Siswa SMP dalam belajar IPA pada Materi Energi Terbarukan: Jurnal Pena Sains, (online), Vol 3, No.2, (http://journal.trunojoyo.ac.id, Diakses 15 Juni 2017.

Depdikbud. (2009). Evaluasi dan Penilaian. Proyek Peningkatan Mutu Guru. Dirjen Dikdasmen, Jakarta.

Hasbullah \& Rahmawati. (2015). Pengaruh Penerapan Metode Hypnoteaching Terhadap Motivasi Belajar Mahasiswa Universitas Indraprasta PGRI: Jurnal Formatif, (online), jilid 5, No.1, (http://journal.lppmunindra.ac.id, Diakses 15 Juni 2017.

Noer, M. (2010). Hypnoteaching for Success Learning. PT. Bintang Pustaka Abadi: Yogyakarta.

Safitri, D. N., \& Purnamasari, N, I. (2017). Evektifitas Pembelajaran Matematika Dengan Hypnoteaching Terhadap Prestasi Mahasiswa Pada Mata Kuliah Geometri II IKIP PGRI Bojonegoro. Jurnal Edumath (online), Vol. 3, No. 1, (http://ejournal.stkipmpringsewu.ac.id, Diakses 15 Juni 2017.

Yustisia, N. (2012). Hypnoteaching. Yogyakarta: AR-Ruzz Media 